\title{
Fiscal policy and monetary integration in Europe: an update
}

Citation for published version (APA):

Candelon, B., Muysken, J., \& Vermeulen, R. (2007). Fiscal policy and monetary integration in Europe: an update. METEOR, Maastricht University School of Business and Economics. METEOR Research Memorandum No. 050 https://doi.org/10.26481/umamet.2007050

Document status and date:

Published: 01/01/2007

DOI:

10.26481/umamet.2007050

Document Version:

Publisher's PDF, also known as Version of record

\section{Please check the document version of this publication:}

- A submitted manuscript is the version of the article upon submission and before peer-review. There can be important differences between the submitted version and the official published version of record.

People interested in the research are advised to contact the author for the final version of the publication, or visit the DOI to the publisher's website.

- The final author version and the galley proof are versions of the publication after peer review.

- The final published version features the final layout of the paper including the volume, issue and page numbers.

Link to publication

\footnotetext{
General rights rights.

- You may freely distribute the URL identifying the publication in the public portal. please follow below link for the End User Agreement:

www.umlib.nl/taverne-license

Take down policy

If you believe that this document breaches copyright please contact us at:

repository@maastrichtuniversity.nl

providing details and we will investigate your claim.
}

Copyright and moral rights for the publications made accessible in the public portal are retained by the authors and/or other copyright owners and it is a condition of accessing publications that users recognise and abide by the legal requirements associated with these

- Users may download and print one copy of any publication from the public portal for the purpose of private study or research.

- You may not further distribute the material or use it for any profit-making activity or commercial gain

If the publication is distributed under the terms of Article $25 \mathrm{fa}$ of the Dutch Copyright Act, indicated by the "Taverne" license above, 
Bertrand Candelon, Joan Muysken, Robert Vermeulen

Fiscal Policy and Monetary Integration in Europe: An Update

$\mathrm{RM} / 07 / 050$

JEL code: E63, H11, H61

\section{METE@R}

Maastricht research school of Economics of TEchnology and ORganizations

Universiteit Maastricht

Faculty of Economics and Business Administration P.O. Box 616

NL - 6200 MD Maastricht

phone : ++31433883830

fax $\quad:++31433884873$ 
18 October 2007

\title{
Fiscal Policy and Monetary Integration in Europe: An Update
}

\author{
Bertrand Candelon ${ }^{\mathrm{a}}$, Joan Muysken ${ }^{\mathrm{a}, \mathrm{c}}$ and Robert Vermeulen ${ }^{\mathrm{a}, \mathrm{b} *}$
}

\begin{abstract}
By distinguishing between discretionary and non-discretionary fiscal policy, this paper analyses the stability of fiscal rules for EMU countries before and after the Maastricht Treaty. Using both Instrumental Variables and GMM techniques, it turns out that discretionary fiscal policy remains procyclical after 1992. This result contradicts the previous findings of Galí and Perotti (2003). It also appears that fiscal rules differ between large and small countries: especially large countries follow a procyclical discretionary policy. Furthermore, the paper shows that discretionary fiscal policy does exhibit different behaviour facing supply or demand constraints. The procyclical discretionary policy is followed mainly during upswings, when supply constraints are prevalent. Finally, there is no support for the presence of a 'fatigue effect' in fiscal discipline.
\end{abstract}

Keywords: discretionary fiscal policy; demand and supply constraints; Maastricht Treaty J.E.L. codes: E63; H11; H61

${ }^{a}$ Department of Economics, Maastricht University, PoBOX 616, 6200 MD Maastricht, The Netherlands

b Department of Economics, University of Luxembourg, 162A Avenue de la Faiencerie, L-1511 Luxembourg, Luxembourg

${ }^{\mathrm{c}}$ Corresponding author (Joan Muysken): Department of Economics, Maastricht University, PoBOX 616, 6200 MD Maastricht, The Netherlands. Tel: +31 04338 83808; Fax: +31 0433884150.

E-mail adress: j.muysken@algec.unimaas.nl

* The authors thank Britta Augsburg and Marcel Mulleners for their assistance with earlier research leading to this article. 


\section{Intraduction}

Fiscal arrangements, which have been settled during the European integration process, constitute undoubtedly the most criticized part of the European Monetary Union (EMU). Even if they aim at increasing real convergence among member countries, they are occasionally perceived among national politicians and European citizens as an unacceptable dictate from Brussels authorities, which removed the possibility of fiscal expansion in face of recessions. In other words, by imposing fiscal rules in the Maastricht Treaty or the Stability and Growth Pact, fiscal policy would have lost its counter-cyclical role and thus the stabilizing effect it used to play in the past.

Empirical studies that have tried to find support for the changing cyclical behaviour of fiscal policy during the European integration process, failed to come to a clear-cut corroboration, and even endorse the fiscal ease introduced by the Maastricht Treaty and the Stability and Growth Pact - see Wyplosz (2006) for a survey. In this respect, the paper of Galí and Perotti (2003) (GP hereafter) constitutes a widely cited example. GP distinguish systematically between discretionary and non discretionary fiscal policy in their analysis. In the first case the variable of interest is the structural deficit, i.e. corrected for cyclical fluctuations, and any change in the public deficit indicates discretionary policy. The non-discretionary part of the fiscal deficit then encompasses the automatic stabilizing effects due to business cycle fluctuations. For example, the public deficit tends to be automatically reduced during upward phases of the cycle, because of an increase in fiscal income.

GP investigate the stability of both components of fiscal policy before and after the signature of the Maastricht Treaty in 1992 through the estimation of a fiscal-rule equation for the period $1980-2002$. As might be expected from the automatic stabilizer effects, non-discretionary fiscal policy clearly shows a counter-cyclical behaviour in the pre-Maastricht period, which even increases after the Maastricht Treaty. Concerning the discretionary part, GP find that fiscal policy was procyclical in the pre-Maastricht period but in the post-Maastricht period this changed into a- or counter-cyclical behaviour. Instead of supporting the weakness of fiscal policy in the constituted EMU, GP therefore conclude that the Maastricht Treaty and the Stability and Growth Pact supported the implementation of fiscal policy, instead of being a restraint. 
This absence of a significant break in 1992 as well as the procyclical pattern of discretionary fiscal policy prior to Maastricht, but acyclical thereafter, has been confirmed by Wyplosz (2006, Table 2) using more recent data and similar estimation procedures. Von Hagen (2006, Table 6) finds that discretionary policy has remained procyclical after Maastricht, but this conclusion is subject to caution as it is based on pooled OLS estimation, which may be biased as we will argue below (in line with GP). ${ }^{1}$ Fatás and Mihov (2003a) stress that the Stability and Growth Pact in its various guises has provided protection against the undesirable consequences of policy discretion by introducing constraints on deficit policy. ${ }^{2}$ They conclude that the Pact has indeed been successful in reducing deficit volatility, in particular for discretionary policy. However, they also observe a "fatigue in the process of fiscal adjustment. Once countries have moved into the safe area below the 3 per cent limit, the pressure to continue towards the goal of close to balance or surplus is much weaker ...”.(p. 121)

This paper extends the GP study to more recent years, since GP is based on data covering the period 1980 - 2002 issued mainly from OECD Economic outlook database. ${ }^{3}$ Extending the sample for the period 2002-2004 provides additional information and removes the problem of data revision, which did affect the observations used by GP. Comparing the results of the estimation for the 1980-2002 and 1980-2004, it turns out that contrary to GP and Wyplosz (2006), discretionary fiscal policy is consistently procyclical over the sample. Furthermore, fiscal policy has not become less procyclical after Maastricht: adding the last two years indicates even greater procyclical behaviour of discretionary fiscal policy. Hence, the fiscal arrangements induced by EMU have in no case constituted an ease but instead have provided less room for effective discretionary fiscal policy. Contrary to GP, our conclusion supports the uneasy feeling among various European politicians. Concerning non-discretionary fiscal policy, the enlarged sample

\footnotetext{
${ }^{1}$ The same holds for the estimations by Fonseca Marinheira (2005).

${ }^{2}$ An interesting observation by von Hagen (2006) is that elections do have an impact on the fiscal behaviour.

${ }^{3}$ Several studies advocate the use of real-time data to judge on the pro- or counter cyclicality of fiscal policies, by using only information actually available to policymakers at the time they make their decisions - e.g. Forni and Momigliano (2004) and Golinelli and Momigliano (2006). However, data availability of real time data is limited. Moreover, the objective of this paper is to evaluate actual fiscal policy conducted by EMU governments and eventually governments are judged on their ex-post performance.
} 
confirms the stabilizing role of automatic stabilizers, which play an increased role since 1992 as predicted by economic theory (Wren-Lewis, 2000; Fatás and Mihov, 2003b).

In our analysis we find strong indications of country heterogeneity. Following the literature we distinguish between different fiscal polices for large and small countries. We find that small countries have more effective discretionary fiscal policies, as expected. The large countries exhibit a different behaviour as they tend to support a procyclical discretionary fiscal policy, without any break in 1992. This small versus large country heterogeneity is not found in the case of non-discretionary fiscal policiy which is counter-cyclical whatever the country and the sample considered.

To complement the analysis we also investigate the reaction of the discretionary and non-discretionary fiscal policy to supply and demand shocks separately. To this aim we use survey information on demand and supply constraints issued from the European Commission's Business and Consumer Survey, EU (2006). It turns out that the procyclical bias of discretionary fiscal policy is most prevalent under supply constraints, i.e. during the upswing, which is consistent with our earlier findings towards debt reduction. Such a result constitutes a striking stylized fact. In line with Kostoris Padoa Schioppa (2006) we also expect a clear distinction between large and small countries in fiscal policy behaviour. Although we found some indications for the expected pattern large countries being the main culprit - it turned out hard to obtain significant results.

The plan of the paper is as follows. In Section 2 we review the GP methodology and show that the results of the fiscal rule differ for an extended sample period. Since we also observe the presence of country heterogeneity, we further investigate the presence of heterogeneity by differentiating between large and small countries in Section 3 and show that country heterogeneity indeed plays a role. Finally, in Section 4 we investigate whether the observed differences in countries reactions can be explained by differences in demand and supply constraints - this turns out to be the case to a limited extent. However, we generally find an asymmetric reaction of discretionary fiscal policy to demand and supply constraints. Conclusions are drawn in Section 5. 
2 Have discretionary and non-discretionary fiscal policies changed since Maastricht?

In line with GP most researchers that have investigated the behaviour of fiscal policy based their analysis on a fiscal rule. The simple link between a budget deficit $\left(d_{t}\right)$ and the output gap $\left(\right.$ gapt $\left._{t}\right)$ can be specified as follows:

$d_{t}=c+a_{1} \cdot \operatorname{gap}_{t}+\varepsilon_{t}$,

where $\varepsilon_{t}$ is white noise. Nevertheless, this over-simplified fiscal rule suffers from several specification and estimation problems. First, it does not take into account the possible dynamics of the budget deficit. For instance, a country facing a huge deficit and a high debt level has less room for a new expansionary fiscal shock and will tend to be more restrictive for the coming fiscal exercise. As a consequence one might expect that the fiscal impulse at time $t$ depends on the past public deficit $\left(d_{t-1}\right)$ and the past stock of debt $\left(b_{t-1}\right)$. Second, there is a clear simultaneity bias between public deficit $\left(d_{t}\right)$ and the output gap $\left(\operatorname{gap}_{t}\right)$. For this reason, GP rightly reject the use of simple (pooled) OLS-estimator and apply an IV-estimator. However, Arrelano and Bover (1995) show that a GMM estimator based on orthogonal deviation might perform better than IV-estimator in the case of a dynamic panel model. Nevertheless, the relative properties of the IV and GMM estimator remain debatable in the econometric literature ${ }^{4}$, and thus we decide to report he results obtained by both methodologies. Third, the core of GP paper consists of a fixedeffects panel data analysis where the fiscal rule is estimated for a group of countries $i$. Thus, our model roughly consists of the estimation of the following fiscal rule:

$d_{i, t}=c_{i}+a_{1} \cdot E_{t-1}\left(g a p_{i, t}\right)+a_{2 \cdot} \cdot d_{i, t-1}+a_{3 \cdot} \cdot b_{i, t-1}+u_{i, t}$,

\footnotetext{
${ }^{4}$ Harris and Matyas (2004) compare the Arrelano-Bover (1995) approach to different IV specifications, showing that the respective properties of these estimators depend on several factors. In particular, they show by simulations that when sample size is finite, GMM may be biased as it considers large instrument matrices.
} 
where $i$ refers to the country dimension and $E_{t-1}\left(\right.$ gap $\left._{i, t}\right)$ is substituted to gap $_{i, t .}$. The instrument space consists of up to two lags of the dependent variable: $d_{i, t-2}$ and $d_{i, t-3 .}{ }^{5}$ Following GP we also add the lagged US output gap $\left(\operatorname{gap}_{U S, t-1}\right)$ to the instrument space. The adequacy of the instruments is tested via the traditional Sargan test. To obtain robust standard errors the White period correction is applied.

In order to directly compare our results to those of GP we also estimate the fiscal rule using a fixed effects Instrumental Variables (IV) estimator, where gap g $_{t}$ is instrumented by the lagged output gap of the country itself, gap $p_{i, t-1}$, and the lagged US output gap, gap US,t-1 $_{\text {. }}$

To investigate whether a changing behaviour in the fiscal policy occurred after the Maastricht Treaty, the coefficients are allowed to take a different value in the periods before and after the Treaty, i.e. in the periods 1980 - 1991 and 1992 - 2004. Equation (2) then is rewritten as follows:

$$
\begin{aligned}
d_{i, t}=c_{i}^{B M}+c_{i}^{A M}+a_{1}{ }^{B M} \cdot E_{t-1}\left(\operatorname{gap}_{i, t}\right)+a_{1}{ }^{A M} \cdot E_{t-1}\left(\text { gap }_{i, t}\right)+ \\
a_{2}{ }^{B M} \cdot d_{i, t-1}+a_{2}{ }^{A M} \cdot d_{i, t-1}+a_{3}{ }^{B M} \cdot b_{i, t-1}+a_{3}{ }^{A M} \cdot b_{i, t-1}+u_{i, t},
\end{aligned}
$$

where $a^{B M}$ and $a^{A M}$ refer to the value of the coefficient during the pre and post-Maastricht periods, respectively. In the case of an unchanged behaviour of fiscal policy after the Treaty, it should be noticed that $a_{1}{ }^{B M}=a_{1}{ }^{A M}$ can be tested via a simple F-test. A comparison of the values of the coefficients $a_{1}^{B M}$ and $a_{l}{ }^{A M}$ would indicate if the ease of the fiscal policy has improved or not. In case the absolute value of $a_{1}$ has increased, this indicates a stronger counter-cyclical behaviour when $a_{1}<0$ or a stronger procyclical behaviour when $a_{1}>0$.

The proxy for fiscal policy is the budget deficit. As in GP, both the actual $\left(d_{t}\right)$ and the structural budget deficit $\left(d_{t}^{*}\right)$ are considered in our study. The variable $d_{t}^{*}$ indicates the discretionary changes in fiscal policies due to decision of fiscal authorities, whereas the variable $d_{t}-d_{t} *$ represents the non-discretionary fiscal policy as it may be subject to changes that are not under the control of the fiscal authorities. An example for this "automatic stabilizing" effect, is the higher ease of non-discretionary fiscal policies

\footnotetext{
${ }^{5}$ Due to the nature of the panel, small $\mathrm{N}$ and large $\mathrm{T}$, it is not feasible to use the entire instrument space composed of all lags of the dependent variable.
} 
during upward movement of the business cycles. ${ }^{6}$ As activity is booming and the positive output gap increases, tax incomes automatically rise, reducing the budget deficit without any action of fiscal authorities. To remove business cycle movements and to have an adequate proxy of the discretionary action of the fiscal authorities, the OECD has constructed data on a structural public deficit. ${ }^{7}$ The discretionary and non-discretionary fiscal rules have the following forms:

$$
\begin{aligned}
& d^{*}{ }_{i, t}=c_{i}^{B M}+c_{i}^{A M}+a_{1}^{B M} \cdot E_{t-1}\left(\text { gap }_{i, t}\right)+a_{1}^{A M} \cdot E_{t-1}\left(\text { gap }_{i, t}\right)+ \\
& a_{2}^{B M} \cdot d^{*}{ }_{i, t-1}+a_{2}^{A M} \cdot d^{*}{ }_{i, t-1}+a_{3}^{B M} \cdot b_{i, t-1}+a_{3}^{A M} \cdot b_{i, t-1}+u_{i, t}^{*} \text {, } \\
& d_{i, t}-d^{*}{ }_{i, t}=c_{i}^{B M}+c_{i}^{A M}+a_{1}^{B M} \cdot E_{t-1}\left(\operatorname{gap}_{i, t}\right)+a_{1}^{A M} \cdot E_{t-1}\left(\operatorname{gap}_{i, t}\right)+ \\
& a_{2}{ }^{B M} \cdot\left(d_{i, t-1}-d^{*}{ }_{i,-1 t}\right)+a_{2}{ }^{A M} \cdot\left(d_{i, t-1}-d^{*}{ }_{i,-1 t}\right)+a_{3}{ }^{B M} \cdot b_{i, t-1}+a_{3}{ }^{A M} \cdot b_{i, t-1}+u_{i, t} .
\end{aligned}
$$

A negative sign of $a_{1}$ indicates a counter-cyclical policy, whereas a positive sign points towards a procyclical policy.

We present the estimation results of the discretionary fiscal rule on the pre and post-Maastricht period for a set of 11 European countries in Tables (1) and (2), respectively, and of the non-discretionary fiscal rule in Table (3). ${ }^{8}$ Annual data over the period 1980 - 2004 are extracted from OECD (2006). The output gap $\left(\right.$ gap $\left._{i, t}\right)$ is defined as the relative deviation of the gross domestic product from the potential output defined by the OECD. ${ }^{9}$ As in GP, the pre-Maastricht period corresponds to 1980 - 1991, whereas we consider two different post-Maastricht samples: the same as in GP, i.e. $1992-2002$, and an extended one running from 1992 to 2004. We found that although the first sample is identical to the one used in GP, our more recent data are somewhat different because of the revision process: it takes more than one year before the OECD produces its definitive

\footnotetext{
${ }^{6}$ In line with the literature we concentrate on the primary government deficit, i.e. excluding interest payments on government debt. The motivation to do this is that the latter are neither discretionary, nor automatic stabilizers - whereas the discussion focuses on the interaction between discretionary policy and automatic stabilizers.

${ }_{8}^{7}$ See the Appendix for data sources.

${ }^{8}$ The countries are Austria, Belgium, Finland, France, Germany, Greece, Ireland, Italy, the Netherlands, Portugal and Spain.

${ }^{9}$ A quick inspection of the data shows that OECD potential output is similar to a trend obtained by applying a Hodrick-Prescott filter with standard $\lambda$ parameters ( $\lambda=400$ for yearly data).
} 
data. ${ }^{10}$ We use four different estimations methods (Pooled Instrumental Variables, IV with fixed effects, IV with different fixed effects before and after Maastricht, and GMM) as well as four different sets of constraints on the fiscal rule (all the coefficients are free, no effect of the past public deficit on its actual level, $a_{2}=0$, or/and no effect of the past stock of debt, $\left.a_{3}=0\right)$.

[Insert Tables 1 and 2]

GP find a significant change in discretionary policy from "procyclical before [... to ...] essentially acyclical after Maastricht.”(GP, p. 550). The comparable unrestricted IVestimates with fixed effects in Table (1) show no significant change. This indicates that the data revision had an impact on the estimation of the fiscal rule. ${ }^{11}$ On the other hand, the more efficient GMM-estimation results indicate a significant change, consistent with GP.

Comparing the results of Tables (1) and (2) also suggests that discretionary fiscal policy has become more procyclical in recent years. That is, when we extend the estimation period to 2004, Table (2) shows quite different results for the GMM-estimates: the marked increase in the coefficient $a_{1}^{A M}$ after Maastricht signals that discretionary fiscal policy remains clearly procyclical after Maastricht - also the coefficient becomes marginally significant, whereas it was insignificant. Using the IV method $a_{1}{ }^{A M}$ even becomes significantly positive when extending the estimation period. The results of the restricted model lead to the same conclusion, except in the case where $a_{2}=0$, on which we comment below.

A closer look at the estimated value of the coefficients $a_{1}^{A M}$ for the various IVestimates in Table (2) reveals some interesting results. First, without restrictions on the

\footnotetext{
${ }^{10}$ Even earlier data is subject to revisions in case previous data turns out to be unreliable or authorities change their statistical calculation methods. The former reason is most pronounced in the revision of Greece's debt and deficit, whereas the latter is present in the revision of GDP figures. These revisions can be quite large, e.g. in the case of Greece the debt GDP/ratio for 2001 is 32 percentage points larger in OECD (2006) than in OECD (2002). However, also for Italy it is 12 percentage points higher, whereas it is 7 percentage points lower for Spain, both for 2001. That earlier data is also revised is illustrated by the observation that the Netherlands' debt/GDP ratio is 15 percentage points higher in 1982 in OECD (2006) than in OECD (2002). For most countries revisions took place, although different in magnitude.

${ }^{11}$ Whereas we find for $a_{1}=0.221(0.052)$ and $0.096(0.076)$, before and after Maastricht respectively, with a p-value of $0.178-\mathrm{cf}$ Table 1 above, GP find $a_{l}=0.17(0.05)$ and $-0.08(0.08)$, respectively, with a pvalue of $0.01-\mathrm{cf}$ their Table 3 .
} 
coefficients we find a marked decrease when we include a fixed country effect - compare the Pooled IV with the Fixed Effect IV estimation. Next, when we allow the fixed effect to be different before and after Maastricht, the country effect is reversed. This suggests that countries have reacted differently to a gap in their discretionary policy after the Treaty, even after controlling for the impact of past debt and deficits. We explore country heterogeneity in more detail in Section 3 below.

As for the impact of past debt and deficits, ignoring the impact of past debt $\left(a_{3}=\right.$ 0 ) leads to a marked increase in procyclicality of discretionary policy after the Treaty for both IV and GMM-estimates. Such changes are not observed before the Treaty for IV, whereas a decrease is visible for GMM. Ignoring the problem of misspecification, which might generate severe statistical distortions at the origin of this result; these observations suggest that the impact of debt on discretionary policy has increased after Maastricht: debt awareness did lead to a more prudent discretionary fiscal policy. This notion is consistent with the findings for GMM-estimates that the negative impact of debt on the deficit is higher after Maastricht, although not significantly so. For the IV estimations, a smaller impact is found if a different pre and post Treaty country fixed effect is used, whereas a higher impact is found if only a single country fixed effect is used. This suggests that (some) countries experienced increased debt awareness in their discretionary fiscal policy after the Treaty.

Excluding the lagged deficit from the fiscal rule leads to a dramatic increase in the procyclicality before the Treaty and a stark decrease thereafter. It is not clear to which extent these results have any meaning due to the presence of severe autocorrelation in the residuals. But whatever the case, both GMM and IV-estimates show similar changes in the estimated value of $a_{l}^{A M}$ when the impact of the lagged deficit is ignored. This could indicate the importance of past budget deficits for the efficiency of the discretionary policy: Ceteris paribus, an equilibrated budget deficit would ease the improvement of an active discretionary fiscal policy. Excluding both debt and lagged deficit from the fiscal rule result in unclear outcomes, moreover severe biases are present due misspecification and serial correlation. Additionally the Sargan test rejects the adequacy of the instrument space.

In general, there appears to be much country heterogeneity and both GMM and fixed effects IV deal with this differently. Although general trends are confirmed by both 
methods, for robustness we will present both GMM and IV estimates (GP methodology) in our further investigations.

[Insert Table 3]

From Table (3) one sees that the results for non-discretionary fiscal policy are quite clear: Whatever the estimation method, a significant increase in the counter-cyclical behaviour of this type of fiscal policy after Maastricht is found - since similar results are found when we estimate for the period until 2002, we do not present these results separately. This confirms the finding of GP that automatic stabilizers took a more important place after the fiscal arrangements induced by the EMU. It is also interesting to observe that neither country specific effects nor restrictions on the impact of deficits and debts had a large impact. This is consistent with the interpretation of non-discretionary policy as truly representing automatic stabilizers.

Finally we have also reproduced all estimations presented in Tables 2 and 3 for the period 1980 - 2006, using the most recent data, which will certainly be revised for the years 2005-6 (for that reason they are not presented separately). The new estimations show the same tendencies as reported above for the discretionary deficit, and the impact of past debt has become even stronger. For the non-discretionary deficit all coefficients are almost identical to the results reported in Table 3.

While the findings on non-discretionary policy are quite robust and consistent with prior notions, the findings on discretionary policy are more volatile both with respect to the estimation period and with respect to the restrictions imposed. However, two general observations can be made. First, a changing behaviour of the discretionary fiscal policy with respect to the output gap before and after Maastricht is rejected. That is, contrary to the findings of GP we find that discretionary fiscal policy has remained procyclical. Moreover, we have strong indications that discretionary fiscal policy has become more procyclical in recent years. A second observation is that we found, again contrary to the findings of GP, that past debt (or deficits) had a stronger impact on discretionary fiscal policy after Maastricht. This leads us to conclude that after Maastricht increased debt awareness has led to much more prudent discretionary policy, in particular in recent 
years. Thus discretionary policy partly neutralized the impact of the automatic stabilizers, in order to keep the deficit under control. We elaborate on this point in the next section and in our concluding remarks.

A final observation is that we have strong indications that countries reacted differently to the Maastricht Treaty in the implementation of their fiscal policy, even after controlling for past debts and deficits.

3 Have discretionary and non-discretionary fiscal policies changed since Maastricht: A large vs. small country dimension

We have argued above that among the 11 European countries under scope, some countries exhibit heterogeneous behaviour. This might imply that our panel analysis leads to an average of country-specific fiscal rules which have little in common. To investigate this possibility we estimate the fiscal rule for each individual country. ${ }^{12}$ To keep the endogeneity bias under control, we use the IV-method with dummies before and after Maastricht to estimate the individual equations.

\section{[Insert Table 4]}

Table (4) summarizes the results of the estimation of these individual fiscal rules. It turns out that the output gap only has a significant effect on discretionary policy after Maastricht for 5 countries: France, Germany, Greece, Italy and Portugal, which all have a consistently procyclical behaviour. Austria, Belgium, and Finland show a countercyclical discretionary fiscal policy, although the impact of the output gap does not differ significantly from zero. ${ }^{13}$ A closer look at the data shows that for both Finland and Portugal the output gap behaves opposite to that of the other European countries, hence Portugal and Finland were probably hit by asymmetric shocks. With respect to Greece,

\footnotetext{
${ }^{12}$ Note that estimation of the fiscal rule for individual countries leads to a small sample bias, i.e. 24 observations for the whole sample. Nevertheless, it gives an indication of the implementation of the fiscal rule at the country level. Following GP we do not distinguish between before and after Maastricht for the coefficients of lagged debt and deficit, in order to limit the number of parameters to be estimated.

${ }^{13}$ Not published results show the discretionary fiscal policy is more procyclical for most countries when including the years 2003 and 2004 in the post-Maastricht sample, supporting our conclusion in Section 2 of a stronger destabilizing role of the discretionary fiscal policy.
} 
the data revision did lead to some quite serious changes to correct for wrong information which Greece presented when entering the EMU.

The non-discretionary fiscal policy exhibits a homogenous picture for all countries: it is significantly counter-cyclical as can be seen from the last two columns of Table (4). This result stresses again the importance of automatic stabilizers in the fiscal stabilization policy and corroborates our conclusion in Section 2. However, from Table (4) one also sees that for none of the countries the impact of the output gap on the nondiscretionary deficit is significantly different before and after the Maastricht treaty. This finding is consistent with the IV estimates reported in Table (2) above.

\section{[Insert Table 5]}

The observed procyclical behaviour of France, Germany and Italy on the one hand and the outlier positions of Finland, Greece and Portugal on the other, indicate the direction of a more systematic investigation of country heterogeneity in discretionary policy. Moreover, employing both the GMM estimator and the fixed effect IV estimator enables us to check the robustness of the estimations and allows for heterogeneity in the explanatory variables before and after Maastricht.

First we show in panel A of Table (5) that excluding the outliers from the estimation results indeed affects the estimation results for the EMU-11. One sees that leaving out the two countries with asymmetric shocks leads to significant procyclical behaviour for the remaining countries after Maastricht. However, when only Greece is excluded the picture changes quite strongly. The procyclical behaviour of discretionary policy before Maastricht changes towards an acyclical stance after Maastricht. This finding, which is in line with GP, still hides significant country specific heterogeneity.

The observed procyclical behaviour of France, Germany and Italy, warrants taking the large countries in the EU from our sample as a group (France, Germany, Italy and Spain) whose behaviour is compared to the small countries (Austria, Belgium, Ireland and the Netherlands). Various studies point to the possibility that small countries will stick much closer to the rules of the Stability and Growth Pact than large countries e.g. de Haan et al. (2003) and von Hagen (2003); see Buti and Pench (2004) and Kostoris Padoa Schioppa (2006) for a survey. 
Observe from panel B in Table (5) that the large countries had a significant procyclical discretionary fiscal policy before Maastricht, which became more significantly procyclical thereafter, whereas the small countries had a significant procyclical policy before Maastricht, but acyclical thereafter. This indeed is consistent with the notion that small countries will stick closer the MT-rules, but does not explain why the large countries should follow a procyclical policy.

A possible explanation for the latter observation is given in von Hagen (2006), who distinguishes between countries following two different institutional approaches: the delegation approach and the contractual approach, respectively - this is further elaborated in Hallerberg et al. (2007). The large countries are characterised by the delegation approach and "the reforms of the budget process strengthening delegation in these countries during the 1990's should have a long-run benefit in terms of higher fiscal discipline" (Hallerberg et al., 2007: 356). ${ }^{14}$ The latter observation is consistent with our finding of a procyclical discretionary policy for these countries.

A quite different interpretation of the situation is provided by Kostoris Padoa Schioppa (2006), who emphasises that it is important to distinguish between demand and supply shocks to understand this phenomenon.

\section{Have discretionary and non-discretionary fiscal policies changed since Masstricht: Decomposing supply and demand constraints}

In search for a different impact of the output gap on the deficit for various countries we look at the different components of the output gap. Business cycle fluctuations can either take their origins in constraints affecting the supply or the demand side. In our view an asymmetric pattern of fiscal policy can be expected to both types of constraints. For instance Calmfors et al. (2003, p.50) state that, in the short run "there is no reason... to believe that the automatic stabilisers give an optimal degree of stabilisation... [On the contrary] if there are permanent supply shocks, the automatic stabilisers tend to prolong the adjustment process and cause budget effects that must ultimately be eliminated through discretionary action". See also Beetsma and Jensen (2004) who emphasize that the effectiveness of a common fiscal policy rule for several countries with imperfectly

\footnotetext{
${ }^{14}$ The reason is that delegation countries give the minister of finance a lot of discretionary power which is easily abused leading to a political business cycle.
} 
correlated supply shocks depends on the extent to which products are close substitutes. A different argument is brought forward by Kostoris Padoa Schioppa (2006), who in line with Uhlig (2003), emphasizes that demand shocks affect inflation indirectly through the output gap, while supply shocks affect inflation directly. This implies that the European Central Bank will react directly to supply shocks (in particular occurring in large countries) and indirectly to demand shocks. Since the EMU countries will take the reaction by the ECB into account when deciding on fiscal policy, demand and supply shocks will have an asymmetric impact, in particular in large countries.

The demand and supply indicators are constructed from disaggregated data of the European Commission's Business and Consumer Survey, EU (2006). We focus on Question 8 in the Industry / Business Climate Indicator (BCI) part, which asks companies to record the most important factor limiting their production. There are six possible answers (financial, demand, labour, equipment, other or none), which are reported in the dataset by a percentage of total firms selecting this choice. We identify the answers 'demand' and 'financial' with demand constraints and 'labour' and 'equipment' with supply constraints. ${ }^{15}$ Hence, it is possible to construct two indicators by simply adding up the shares of the firms answering 'demand' and 'financial' to define the demand constraint $\left(D_{t}\right)$ and of the shares answering 'labour' and 'equipment' for the supply constraint $\left(S_{t}\right)$ - the shares answering 'none' and 'other' form the last category, 'no constraint'. A higher value for each constraint indicates that the constraint is more prevalent. Demand and supply variables have a quarterly frequency, but have been annualized using an arithmetic average, and cover the period 1985 to 2004 for all countries of our sample, except Austria and Finland for which no data were available. ${ }^{16}$ Demand and supply variables are presented in Figure 1.

\section{[Insert Figure 1]}

From Figure 1 one sees that demand and supply constraints typically follow the cycle in a counter-cyclical and procyclical way, respectively. As a consequence demand

\footnotetext{
15 The inclusion of financial constraints under demand constraints follows from the notion that credit rationing constrains demand (Van der Ploeg, 2005).

${ }^{16}$ The data on Austria starts only in 1996:Q1 and on Finland in 1995:Q4. Portugal and Spain are included although data are missing for 1985 and 1986.
} 
and supply constraints co-move strongly. Another observation is that there is a difference in the shares of firms reporting demand and supply constraints over countries. For instance, in Germany on average 40 per cent of the firms indicate having demand constraints, while only 5 percent on average reports supply constraints. In France the corresponding shares are 25 and 30 percent, respectively. The differences following from different reporting behaviour across countries will not affect our estimation results, however, since these will be included in the fixed effects.

The (discretionary or non-discretionary) fiscal rule can be expressed in terms of demand $\left(D_{t}\right)$ and supply $\left(S_{t}\right)$ constraints, instead of the output gap variable $\left(\right.$ gap $\left._{t}\right)$. This is expressed in equation (5):

$a_{1}^{X} \cdot E_{t-1}\left(\operatorname{gap}_{i, t}\right)=a_{1 D}{ }^{X} \cdot E_{t-1}\left(D_{i, t}\right)+a_{1 S}^{X} \cdot E_{t-1}\left(S_{i, t}\right) \quad X=A M, B M$

As a consequence the equations to be estimated follow from substituting equation (5) in equations (3) and (4), respectively. ${ }^{17}$

The estimation results are presented for discretionary and non-discretionary policy in panel A of Tables (6) and (7), respectively. To allow for a fair comparison with previous results, we present in both tables in the first line also the results of estimating the output gap $\left(\operatorname{gap}_{t}\right)$. Finally, the inspection of Figure 1 indicates us that supply and demand variables co-move strongly with each other, albeit inversely. ${ }^{18}$ It is thus likely that estimating an equation containing both of them will lead to multicollinearity bias. Hence, we also estimate equations (3) and (4) separately with the demand and the supply constraint alone. These results are presented in panel B of both Tables. Finally we included in panel $\mathrm{C}$ the results obtained when leaving out debt from the estimation results of panel B (imposing $a_{3}=0$ ).

Comparing Table (6) with Table (2) shows that leaving out Austria and Finland results in an increase in the estimated impact of the output gap on discretionary policy for

\footnotetext{
${ }^{17}$ The category 'no constraint', which makes up for the full one hundred per cent of the output gap then is a default and included in the constant term. This allows us to ignore the large differences in reported 'no constraints' over countries - the category 'other' is negligibly small. Kostoris Padoa Schioppa (2006) overcomes this problem by looking at the ratio $D_{t} / S_{t}$, but this ratio shows a highly volatile pattern, since $D_{t}$ and $S_{t}$ usually move in opposite directions.

${ }^{18}$ Fixed effect estimation of demand on supply constraints yields a highly significant coefficient of -1 .
} 
the post-Maastricht period. Since the shorter sample period, starting in 1985 instead of 1980, can hardly be held be held responsible for differences in the post-Maastricht results, the smaller sample of countries should be held responsible. However, the results for non-discretionary policy barely change when leaving out Austria and Finland as can be seen from Tables (3) and (7). These observations emphasize the heterogeneity of country reactions in case of discretionary policy which we also found in the previous section.

[Insert Tables 6 and 7]

When further comparing the estimation results, one should realize that a demand constraint should be associated with a negative output gap, and a supply constraint with a positive output gap. ${ }^{19}$ Therefore one might expect the same sign for $a_{1}$ and $a_{1 S}$, and an opposite sign for $a_{1 D}$.

Looking first at the case of non-discretionary policy panel A in Table (7) shows that the impact of supply constraints is consistently negative whenever significant. Also both GMM and IV indicate that supply constraints have a significantly stronger impact after Maastricht. However, the impact of demand constraints is less clear: the IVestimation results are consistent with predictions, i.e. it has a positive impact, whereas GMM yields insignificant results.

When estimating the effects separately, panel B of Table (7) shows that in the case of non-discretionary policy all results are consistent with expectations - the impact of demand and supply constraints is consistently positive and negative, respectively, for both GMM and IV. These results are confirmed and even stronger when we exclude the impact of debt, as can be seen from panel C. When excluding the impact of debt, nondiscretionary policy reacts consistently positive to demand shocks, with a stronger reaction after Maastricht.

Since panel A shows no significant impact of demand shocks, this points to a hampering impact of debt awareness on the working of the automatic stabilisers during downturns. Moreover, in both panels A and B the supply constraints have a significantly

\footnotetext{
19 This is confirmed by fixed effect estimation of the output gap on demand and supply constraints, which yields highly significant results - the results are obtainable on request from the authors.
} 
stronger impact after Maastricht, suggesting that the automatic stabilisers are much more active in reducing the deficit after Maastricht - both compared to the pre-Maastricht period and to the impact of demand constraints. This also points to a tendency of a stricter budget policy - in particular after Maastricht.

Turning to discretionary policy the estimation results in panel A of Table (6) indicate that using GMM and IV one finds consistently that discretionary policy does not seem to react to supply and demand shocks: no significant impact is found - only a weak significant result for supply constraints can be observed in case of IV. However, both methods show that the output gap has a strong procyclical impact on the deficit.

This latter observation is confirmed in panel B of Table (6), showing the impact of both demand and supply shocks when estimated separately. The impact of both types of shocks is significant according to the IV-estimations. For both types of shocks the impact turns out to be much stronger after Maastricht. Panel C confirms and strengthens these findings, although excluding the impact of debt does not affect these results strongly. Finally, one sees that in the period after Maastricht supply shocks have a much stronger impact than demand shocks, as is the case with non-discretionary policy. ${ }^{20}$ Our estimations are consistent with Fonseca Marinheira (2005) who finds an asymmetric impact of procyclical policy and concludes: "Thus, in general, discretionary fiscal policy is procyclical in upswings and counter-cyclical in downswings."(p.9)

[Insert Tables 8 and 9]

When considering country heterogeneity along the line of section 3 - see Table (5) - we find no significant impact of demand or supply constraints on the discretionary budget deficit when using GMM for the full sample of countries - cf. Panel A of Tables (8) and (9). The IV results show, however, a highly significant procyclical impact of supply constraints after Maastricht.

When focussing on large countries instead - cf. panel B of Tables (8) and (9) - neither demand shocks nor supply shocks are significant after Maastricht. However, the GMM-

\footnotetext{
${ }^{20}$ The fixed effects estimation of the output gap on demand and supply constraints shows no stronger impact of the supply constraints on the output gap compared to the impact of demand constraints.
} 
results indicate a significant decrease in the impact of demand constraints compared to the period before Maastricht and an almost significant increase in the impact of supply constraints. The results for the small countries show no clear pattern. This picture is stronger for the IV-results, which show that the highly significant procyclical impact of supply constraints after Maastricht found for all countries is due to the highly significant impact of supply constraints for the large countries.

In conclusion, the decomposition of the output gap in demand and supply constraints illuminates that in general the EMU9 countries have reacted in an asymmetric way to demand and supply shocks. The estimation results indicate that non-discretionary policy was more focussed on reducing the deficit after Maastricht: the counter-cyclical reaction to supply constraints was stronger, both compared to the pre-Maastricht period and to the

impact of demand constraints. Similar results were found for the procyclical discretionary policy. Again supply shocks were found to have a much stronger impact than demand shocks in the period after Maastricht.

The results also shed more light on country heterogeneity in discretionary policy. Consistent with the results from the previous section we find that the procyclical discretionary policy is mainly present in large countries. But the results of this section show that procyclical policy only occurs during upswings, when supply constraints are more binding.

\section{Conclusion}

In evaluating the impact of the Maastricht Treaty on fiscal policy in the EMU countries, Galí and Perotti (2003) find that the automatic stabilisers are more effective in countercyclical stabilisation after the implementation of the Treaty, while the procyclical stance of discretionary fiscal policy before Maastricht turns to an acyclical stance thereafter. From these findings Galí and Perotti conclude that the fiscal rules implied by Maastricht (and by the Stability and Growth Pact) do not imply an unnecessary and harmful straight jacket for fiscal policy in the EMU countries.

Using an extended sample size and revised data, this paper puts some shadow on this optimistic finding of Galí and Perotti. We show that the procyclical behaviour of the 
fiscal discretionary policy has not disappeared with the Maatricht Treaty, but instead it persisted and was even amplified in recent years. Such a result stresses that the fiscal arrangements that followed the Maastricht Treaty indeed tied the hands of European governments in their implementation of stabilizing discretionary fiscal policy.

This conclusion corroborates the result of Fatás and Mihov (2003a) who attribute it to a 'fatigue effect'. They illustrate this by presenting two trends over the period 1991 2001. In their Figure 4 they portray the average value of change in the cyclically adjusted budget of the Euro countries. The decline of this value over the period 1991 - 1999 indicates "a trend towards smaller changes in discretionary policy. ...[However], since 1999 , this measure of discretionary fiscal policy is picking up again. In other words, in 2000 and 2001 governments deviated more from their cyclically adjusted budget positions than in previous years." (122) - this is indicative of the fatigue effect: "Once countries have moved into the safe area below the 3 percent limit, the pressure to continue towards the goal of close to balance or surplus is much weaker and it shows in the data."(121) Similar observations are made by Fatás and Mihov (2003a) from their Figure 8 , in which they present the standard deviation of change in the cyclically adjusted budget of the Euro countries. They find that the dispersion after a decreasing trend until 1999 also has higher values in 2000 and 2001.

[Insert Figures 2 and 3]

We reproduce both series for our sample for the period 1980 - 2006 in Figures 2 and $3 .{ }^{21}$ The decline Fatás and Mihov (2003a) report for the 1990s is also clearly visible in our data. However, this decline starts in the 1980s as can be seen from our data, which contradicts Fatás and Mihov's focus on the 1990s and the Maastricht Treaty. Moreover, Figure 2 clearly illustrates the procyclical nature of discretionary policy, which we find consistently in our earlier analysis - compare for instance the impact of the recessions in 1987, 1991 and 2001. The latter recession also illustrates that the interpretation by Fatás and Mihov (2003a) of the increased discretionary budget deficit in 2000 and 2001 is not due to a fatigue effect, but rather due to the procyclical nature of discretionary policy, in

\footnotetext{
${ }^{21}$ One should realize that Fatás and Mihov (2003a) use a different method to identify discretionary deficits than the OECD, based on the estimated residual of a government spending equation - see Fatás and Mihov (2003b).
} 
particular during upswings: when the business cycle picks up again, the discretionary deficit decreases. Figure 3 clearly illustrates the country heterogeneity we report above, the larger spread during recessions illustrates the different reactions of large and small member states discussed in Section 3 above.

The economic stance appears as a key factor for the characterization of fiscal policy. In a recent paper Manasse (2005) distinguishes between on the one hand "very good" and "very bad" economic times, and on the other hand "intermediate states". He then derives a simple model where limits on deficit output ratios lead to procyclical policies only in intermediate states, and to countercyclical policies in the other cases. Empirical investigations are now necessary to assess this idea and these will constitute a promising future research field. It will nevertheless be necessary to overcome some technical problems, in particular those associated with the low number of observations (only few business cycles have been observed since 1992). 


\section{References}

Arellano, M. and O. Bover (1995), Another look at the instrumental variable estimation of error-components models, Journal of Econometrics, 68 (1), 29-51.

Beetsma, R. and Jensen, H. (2004), Mark-up Fluctuations and Fiscal Policy Stabilization in a Monetary Union, Journal of Macroeconomics, 26 (2), 357-376.

Buti, M. and L.R. Pench (2004), Why Do Large Countries Flout the Stability Pact? And What Can Be Done About It?, Journal of Common Market Studies, 42 (5), 1025-1032.

EU (2006), European Commission's Business and Consumer Survey, http://ec.europa.eu/economy_finance/indicators/businessandconsumersurveys_en.htm

Fatás, A. and Mihov, I. (2003a), On Constraining Fiscal Policy Discretion in EMU, Oxford Review of Economic Policy, 19 (1), 112-131.

Fatás A. and I. Mihov (2003b), The Case for Restricting Fiscal Policy Discretion, The Quarterly Journal of Economics, 118 (4), 1419-1447.

Forni, L. and S. Momigliano (2004), Cyclical Sensitivity of Fiscal Policies Based on Real-Time Data, Bank of Italy Economic Research Paper, No. 540.

Galí, J. and R. Perotti (2003), Fiscal Policy and Monetary Integration in Europe, Economic Policy, 18 (37), 534-572.

Golinelli, R. and S. Momigliano (2006), Real-Time Determinants of Fiscal Policies in the Euro Area: Fiscal Rules, Cyclical Conditions and Elections, Journal of Policy Modeling, (28), 943-964.

De Haan, J., H. Berger and D. Jansen (2003), The End of the Stability and Growth Pact?, CESIfo Working Paper, No. 1093.

Hallerberg, M, R. Strauch and J. von Hagen (2007), The Design of Fiscal Rules and Forms of Governance in European Union Countries, European Journal of Political Economy, 23 (2), 338-359.

Kostoris Padoa Schioppa, F. (2006), The 2005 Reform of the Stability and Growth Pact: Too Little, Too Late?, Bruges European Economic Research Papers, No. 6.

Manasse, P, Deficit Limits, Budget Rules, and Fiscal Policy, IMF Working Paper, $\mathrm{WP} / 05 / 120$.

Fonseca Marinheiro, C. (2005), Has the Stability and Growth Pact Stabilised? Evidence from a Panel of 12 European Countries and some Implications for the Reform of the Pact., CESIfo Working Paper, No. 1411.

Harris, N. and L. Matyas (2004), A comparative Analysis of Different IV and GMM estimators of dynamic Panel Data Models, International Statistical Review, 72(3), 397408.

OECD (2002), Economic Outlook Database Inventory, EO72 December 2002 version, http://www.oecd.org/dataoecd/54/59/37380381.pdf.

OECD (2006), Economic Outlook Database Inventory, EO79 August 2006 version, http://www.oecd.org/dataoecd/54/59/37380381.pdf.

Ploeg van der, F. (2005), Back to Keynes?, CESIfo Working Paper, No. 1424.

Uhlig, H. (2003), One Money But Many Fiscal Policies in Europe: What Are the Consequences?, in Buti, M. (eds.), Monetary and Fiscal Policies in EMU, Cambridge, Cambridge University Press, 29-56.

Von Hagen, J. (2006), Fiscal Rules and Fiscal Performance in the EU and Japan, GESY Discussion Paper, No. 147.

Von Hagen, J. (2003), Fiscal Discipline and Growth in Euroland: Experiences With the Stability and Growth Pact, ZEI Working Paper, No. B06. 
Wren-Lewis, S. (2000), The Limits to Discretionary Fiscal Stabilization Policy, Oxford Review of Economic Policy, 16 (4), 92-105.

Wyplosz, C. (2006), European Monetary Union: The Dark Side of a Major Success, Economic Policy, 21 (46), 208-261. 


\section{Data Appendix}

Source: OECD Economic Outlook 79 (June 2006)

- Primary Government Balance, Cyclically Adjusted,

- Primary Government Balance,

- Output Gap,

- Gross Government Debt.

Note: For Germany until 1990 the series for West-Germany has been used and from 1991 onwards data for Germany.

Data is available from 1979-2007, but for some countries the data is extended backward:

- Primary government balance Ireland, the Netherlands and Spain (1979)

- Gross Government debt Ireland (1979-1997), Italy (1979-1994), Portugal (19791994) and Spain (1979-1989)

The extension for gross government debt has been performed by taking the ratio of old data versus new for the first three years for which both are available and taking the average of the ratios. Since these do not differ much, the data is extended back by multiplying the old with the respective ratio. The "old" data are the data used by Galí and Perotti (2003). Primary government balance is estimated in a similar fashion for the single year 1979.

The cyclical part of deficit is calculated by converting the primary government balance as a percentage of potential GDP by: Primary gov't balance*(100-output gap)/100 and subtracting the Cyclically adjusted primary government balance from it. The differences are relatively small.

A detailed description of the data can be found in the OECD's Economic Outlook Database Inventory: http://www.oecd.org/dataoecd/54/59/37380381.pdf (EO79 August 2006 version). 

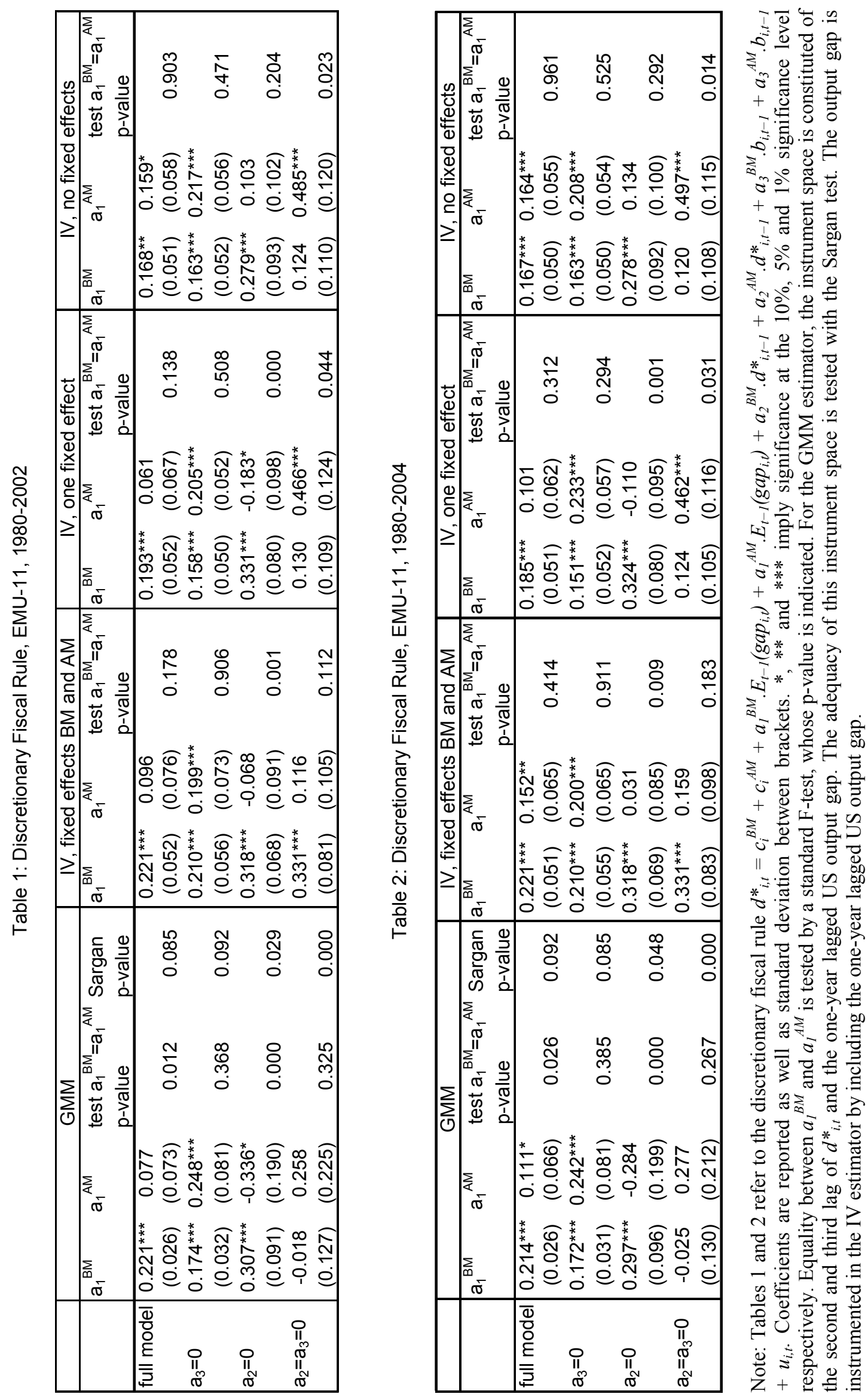


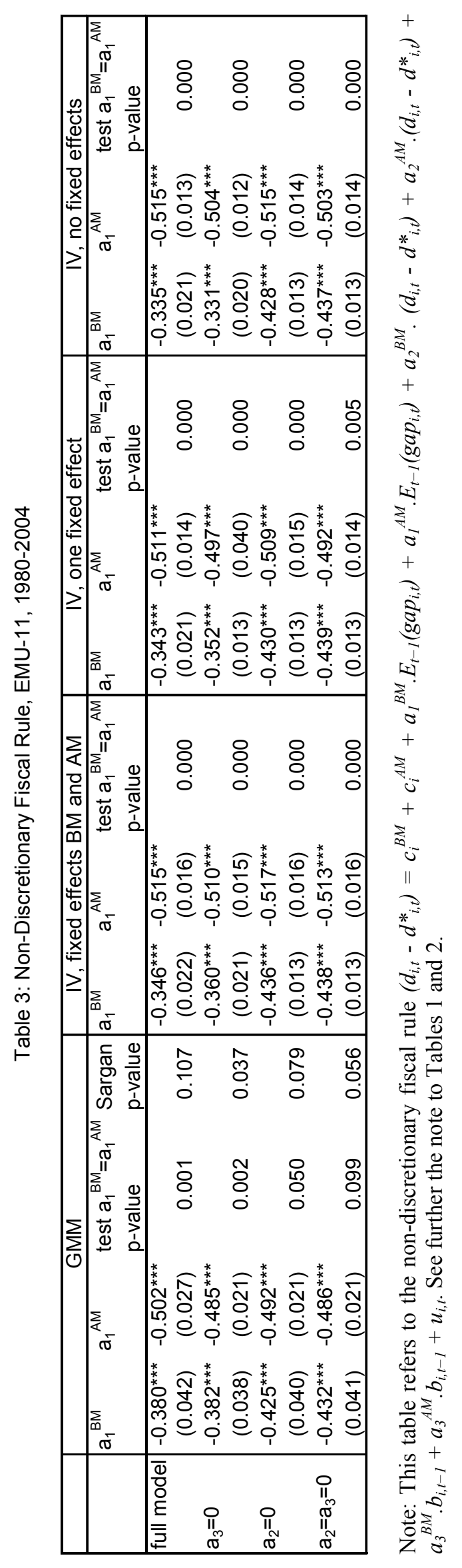


Table 4: EMU Individual Fiscal Rule 1980-2004

\begin{tabular}{|l|ccc|ccc|}
\hline & \multicolumn{3}{|c|}{ Discretionary } & \multicolumn{3}{c|}{ Non-discretionary } \\
\hline country & $\mathrm{a}_{1}{ }^{\mathrm{BM}}$ & $\mathrm{a}_{1}{ }^{\mathrm{AM}}$ & test $\mathrm{a}_{1}{ }^{\mathrm{BM}}=\mathrm{a}_{1}{ }^{\mathrm{AM}}$ & $\mathrm{a}_{1}{ }^{\mathrm{BM}}$ & $\mathrm{a}_{1}{ }^{\mathrm{AM}}$ & test $\mathrm{a}_{1}{ }^{\mathrm{BM}}=\mathrm{a}_{1}{ }_{1}{ }^{\mathrm{AM}}$ \\
\hline BUT & 0.042 & -0.172 & & $-0.428^{* * *}$ & $-0.487^{* * *}$ & \\
& $(0.183)$ & $(0.324)$ & 0.552 & $(0.080)$ & $(0.094)$ & 0.305 \\
BEL & 0.356 & -0.482 & & $-0.617^{* * *}$ & $-0.754^{* * *}$ & \\
& $(0.251)$ & $(0.694)$ & 0.253 & $(0.066)$ & $(0.110)$ & 0.233 \\
DEU & $0.450^{* * *}$ & $0.474^{* *}$ & & $-0.517^{* * *}$ & $-0.781^{* * *}$ & \\
& $(0.103)$ & $(0.207)$ & 0.918 & $(0.104)$ & $(0.190)$ & 0.142 \\
ESP & 0.097 & 0.017 & & $-0.460^{* * *}$ & $-0.482^{* * *}$ & \\
FIN & $(0.117)$ & $(0.215)$ & 0.762 & $(0.102)$ & $(0.079)$ & 0.648 \\
& 0.162 & -0.282 & & $-0.417^{* * *}$ & $-0.620^{* * *}$ & \\
FRA & $(0.362)$ & $(0.206)$ & 0.321 & $(0.096)$ & $(0.092)$ & 0.001 \\
& 0.175 & $0.484^{*}$ & & $-0.408^{* * *}$ & $-0.456^{* * *}$ & \\
GRC & $(0.123)$ & $(0.245)$ & 0.291 & $(0.031)$ & $(0.032)$ & 0.153 \\
& 0.088 & $1.173^{* * *}$ & & $-0.345^{* * *}$ & $-0.352^{* * *}$ & \\
IRE & $(0.377)$ & $(0.352)$ & 0.059 & $(0.043)$ & $(0.036)$ & 0.853 \\
& $0.748^{* *}$ & 0.669 & & $-0.450^{* * *}$ & $-0.346^{* * *}$ & \\
ITA & $(0.341)$ & $(0.452)$ & 0.800 & $(0.041)$ & $(0.033)$ & 0.042 \\
& $0.373^{*}$ & $0.567^{* *}$ & & $-0.428^{* * *}$ & $-0.483^{* * *}$ & \\
NLD & $(0.207)$ & $(0.256)$ & 0.556 & $(0.059)$ & $(0.069)$ & 0.349 \\
& 0.309 & 0.212 & & $-0.484^{* * *}$ & $-0.470^{* * *}$ & \\
PRT & $(0.179)$ & $(0.252)$ & 0.781 & $(0.045)$ & $(0.046)$ & 0.806 \\
& $0.371^{* * *}$ & $0.319^{* *}$ & & $-0.309^{* * *}$ & $-0.427^{* * *}$ & \\
& $(0.075)$ & $(0.148)$ & 0.739 & $(0.017)$ & $(0.029)$ & 0.000 \\
\hline
\end{tabular}

Note: This table refers to the discretionary and non-discretionary fiscal rules $d^{*}{ }_{i, t}=c_{i}^{B M}+c_{i}^{A M}+$ $a_{1}^{B M} \cdot E_{t-1}\left(\operatorname{gap}_{i, t}\right)+a_{1}^{A M} \cdot E_{t-1}\left(\operatorname{gap}_{i, t}\right)+a_{2}{ }^{B M} \cdot d^{*}{ }_{i, t-1}+a_{2}^{A M} \cdot d^{*}{ }_{i, t-1}+a_{3}^{B M} \cdot b_{i, t-1}+a_{3}^{A M} \cdot b_{i, t-1}+u_{i, t}$ and $\left(d_{i, t}-d^{*}{ }_{i, t}\right)$ $=c_{i}^{B M}+c_{i}^{A M}+a_{1}^{B M} \cdot E_{t-1}\left(\operatorname{gap}_{i, t}\right)+a_{1}^{A M} \cdot E_{t-1}\left(\operatorname{gap}_{i, t}\right)+a_{2}^{B M} \cdot\left(d_{i, t}-d^{*}{ }_{i, t}\right)+a_{2}^{A M} \cdot\left(d_{i, t}-d^{*}{ }_{i, t}\right)+a_{3}^{B M} \cdot b_{i, t-1}+$ $a_{3}^{A M} \cdot b_{i, t-1}+u_{i, t}$. Coefficients are reported as well as standard deviation between brackets. *, ** and *** imply significance at the $10 \%, 5 \%$ and $1 \%$ significance level respectively. Equality between $a_{l}^{B M}$ and $a_{l}^{A M}$ is tested by a standard F-test, whose p-value is indicated. The output gap is instrumented in the IV estimator by including the one-year lagged US output gap. 
Table 5: Country heterogeneity (output gap EMU11, 1980-2004)

\begin{tabular}{|c|c|c|c|c|c|c|c|}
\hline & \multicolumn{4}{|c|}{ GMM } & \multicolumn{3}{|c|}{ IV } \\
\hline Countries & $a_{1}{ }^{B M}$ & $a_{1}{ }^{A M}$ & test $a_{1}{ }^{B M}=a_{1}$ & Sargan & $a_{1}^{B M}$ & $a_{1}{ }^{A M}$ & test $a_{1}{ }^{B M}=a_{1}{ }^{A M}$ \\
\hline \multicolumn{8}{|c|}{ Panel A: EMU11 and outliers } \\
\hline EMU11 & $\begin{array}{c}0.214^{* \star *} \\
(0.026)\end{array}$ & $\begin{array}{c}0.111^{*} \\
(0.066)\end{array}$ & 0.026 & 0.092 & $\begin{array}{c}0.221^{* * *} \\
(0.051)\end{array}$ & $\begin{array}{l}0.152^{* *} \\
(0.065)\end{array}$ & 0.414 \\
\hline \multirow[t]{2}{*}{ EMU11 (excl. FIN \& PRT) } & $0.217^{* * *}$ & $0.183^{\star *}$ & & & $0.222^{* * *}$ & $0.389^{* * *}$ & \\
\hline & $(0.029)$ & $(0.078)$ & 0.615 & 0.040 & $(0.060)$ & $(0.089)$ & 0.120 \\
\hline \multirow[t]{2}{*}{ EMU11 (excl. GRC) } & $0.194^{* * *}$ & 0.067 & & & $0.246^{* * *}$ & 0.074 & \\
\hline & $(0.028)$ & $(0.076)$ & 0.040 & 0.521 & $(0.048)$ & $(0.067)$ & 0.038 \\
\hline \multirow[t]{2}{*}{ EMU11 (excl. FIN/GRC/PRT) } & $0.194^{* * *}$ & $0.144^{*}$ & & & $0.254^{* * *}$ & $0.290^{* * *}$ & \\
\hline & $(0.038)$ & $(0.078)$ & 0.530 & 0.253 & $(0.054)$ & $(0.095)$ & 0.746 \\
\hline \multicolumn{8}{|c|}{ Panel B: Large vs. Small countries } \\
\hline DEU/ESP/FRA/ITA & $\begin{array}{c}0.204^{\star \star \star} \\
(0.069)\end{array}$ & $\begin{array}{l}0.284^{* *} \\
(0.109)\end{array}$ & 0.325 & 0.272 & $\begin{array}{c}0.254^{* * *} \\
(0.071)\end{array}$ & $\begin{array}{c}0.410^{* * *} \\
(0.122)\end{array}$ & 0.272 \\
\hline \multirow[t]{2}{*}{ AUT/BEL/FIN/GRC/IRE/NLD/PRT } & $0.222^{* * *}$ & 0.070 & & & $0.210^{* * *}$ & 0.102 & \\
\hline & $(0.029)$ & $(0.088)$ & 0.018 & 0.443 & $(0.070)$ & $(0.080)$ & 0.312 \\
\hline \multirow[t]{2}{*}{ AUT/BEL/IRE/NLD } & $0.265^{\star * *}$ & $0.053^{*}$ & & & $0.260^{* * *}$ & 0.208 & \\
\hline & $(0.058)$ & $(0.028)$ & 0.000 & 0.437 & $(0.093)$ & $(0.145)$ & 0.767 \\
\hline
\end{tabular}

Note: This table refers to the discretionary fiscal rule $d_{i, t}^{*}=c_{i}^{B M}+c_{i}^{A M}+a_{1}^{B M} . E_{t-1}\left(g^{A M p_{i, t}}\right)+$ $a_{1}^{A M} \cdot E_{t-1}\left(\operatorname{gap}_{i, t}\right)+a_{2}{ }^{B M} \cdot d^{*}{ }_{i, t-1}+a_{2}{ }^{A M} \cdot d^{*}{ }_{i, t-1}+a_{3}{ }^{B M} \cdot b_{i, t-1}+a_{3}{ }^{A M} \cdot b_{i, t-1}+u_{i, t}$. Coefficients are reported as well as standard deviation between brackets. $*$, ** and *** imply significance at the $10 \%, 5 \%$ and $1 \%$ significance level respectively. Equality between $a_{l}^{B M}$ and $a_{l}^{A M}$ is tested by a standard F-test, whose pvalue is indicated. For the GMM estimator, the instrument space is constituted of the second and third lag of the dependent variable and the one-year lagged US output gap. The adequacy of this instrument space is tested with the Sargan test. The output gap is instrumented in the IV estimator by including the one-year lagged US output gap. 
Table 6: Discretionary fiscal policy, EMU9 1986-2004

\begin{tabular}{|c|c|c|c|c|c|c|c|}
\hline & \multicolumn{4}{|c|}{ GMM } & \multicolumn{3}{|c|}{ IV } \\
\hline & $a_{1}{ }^{B M}$ & $a_{1}{ }^{A M}$ & $\begin{array}{l}\text { test } a_{1}{ }^{B M}=a_{1}{ }^{A n} \\
p \text {-value }\end{array}$ & $\begin{array}{l}\text { Sargan } \\
\text { p-value }\end{array}$ & $a_{1}{ }^{B M}$ & $a_{1}^{A M}$ & $\begin{array}{l}\text { test } a_{1}{ }^{B M}=a_{1}{ }^{A M} \\
p \text {-value }\end{array}$ \\
\hline \multicolumn{8}{|c|}{ Panel A: Both demand and supply in (3) } \\
\hline Output gap & $\begin{array}{l}0.189^{* *} \\
(0.078)\end{array}$ & $\begin{array}{l}0.172^{* \star} \\
(0.071)\end{array}$ & 0.883 & 0.183 & $\begin{array}{l}0.203^{* * *} \\
(0.076)\end{array}$ & $\begin{array}{l}0.360^{* * *} \\
(0.075)\end{array}$ & 0.143 \\
\hline \multirow[t]{2}{*}{ Demand } & -0.020 & -0.008 & & & 0.022 & -0.003 & \\
\hline & $(0.029)$ & $(0.038)$ & 0.404 & 0.246 & $(0.041)$ & $(0.056)$ & 0.721 \\
\hline \multirow[t]{2}{*}{ Supply } & 0.025 & 0.069 & & & 0.126 & $0.215^{*}$ & \\
\hline & $(0.063)$ & $(0.084)$ & 0.442 & 0.246 & $(0.096)$ & $(0.110)$ & 0.546 \\
\hline \multicolumn{8}{|c|}{ Panel B: Either demand or supply in (3) } \\
\hline Demand & $\begin{array}{l}-0.031 \\
(0.021)\end{array}$ & $\begin{array}{l}-0.023 \\
(0.019)\end{array}$ & 0.508 & 0.275 & $\begin{array}{l}-0.021 \\
(0.019)\end{array}$ & $\begin{array}{c}-0.101^{* * *} \\
(0.033)\end{array}$ & 0.037 \\
\hline \multirow[t]{2}{*}{ Supply } & 0.052 & $0.092^{*}$ & & & 0.069 & $0.220 * * *$ & \\
\hline & $(0.040)$ & $(0.048)$ & 0.484 & 0.347 & $(0.048)$ & $(0.065)$ & 0.066 \\
\hline \multicolumn{8}{|c|}{ Panel C: Either demand or supply in (3) with a3=0 } \\
\hline Output gap & $\begin{array}{c}0.167^{* * *} \\
(0.057)\end{array}$ & $\begin{array}{c}0.289^{\star * *} \\
(0.078)\end{array}$ & 0.234 & 0.072 & $\begin{array}{l}0.159^{* *} \\
(0.072)\end{array}$ & $\begin{array}{c}0.362^{* * *} \\
(0.068)\end{array}$ & 0.041 \\
\hline \multirow[t]{2}{*}{ Demand } & $-0.027^{* *}$ & $-0.040^{* * *}$ & & & -0.013 & $-0.103^{* * *}$ & \\
\hline & $(0.012)$ & $(0.013)$ & 0.008 & 0.079 & (0.019) & $(0.031)$ & 0.016 \\
\hline \multirow[t]{2}{*}{ Supply } & $0.098^{* *}$ & $0.115^{\star * *}$ & & & 0.055 & $0.252^{* * *}$ & \\
\hline & $(0.049)$ & $(0.041)$ & 0.763 & 0.440 & $(0.051)$ & $(0.069)$ & 0.023 \\
\hline
\end{tabular}

Note: This table refers to the discretionary fiscal rule $d_{i, t}^{*}=c_{i}^{B M}+c_{i}^{A M}+a_{l}^{B M} \cdot E_{t-l}\left(\operatorname{gap}_{i, t}\right)+$ $a_{1}^{A M} \cdot E_{t-1}\left(\operatorname{gap}_{i, t}\right)+a_{2}^{B M} \cdot d^{*}{ }_{i, t-1}+a_{2}^{A M} \cdot d^{*}{ }_{i, t-1}+a_{3}^{B M} \cdot b_{i, t-1}+a_{3}^{A M} \cdot b_{i, t-1}+u_{i, t}$. Coefficients are reported as well as standard deviation between brackets. $*, * *$ and $* * *$ imply significance at the $10 \%, 5 \%$ and $1 \%$ significance level respectively. Equality between $a_{l}^{B M}$ and $a_{l}^{A M}$ is tested by a standard F-test, whose pvalue is indicated. For the GMM estimator, the instrument space is constituted of the second and third lag of the dependent variable and the one-year lagged US output gap. The adequacy of this instrument space is tested with the Sargan test. The output gap is instrumented in the IV estimator by including the one-year lagged US output gap. 
Table 7: Non-discretionary fiscal policy, EMU9 1986-2004

\begin{tabular}{|c|c|c|c|c|c|c|c|}
\hline & \multicolumn{4}{|c|}{ GMM } & \multicolumn{3}{|c|}{ IV } \\
\hline & $a_{1}{ }^{B M}$ & $a_{1}{ }^{A M}$ & $\begin{array}{l}\text { test } a_{1}{ }^{B M}=a_{1}{ }^{A l} \\
\text { p-value }\end{array}$ & $\begin{array}{l}\text { Sargan } \\
\text { p-value }\end{array}$ & $a_{1}{ }^{B M}$ & $a_{1}{ }^{A M}$ & $\begin{array}{l}\text { test } a_{1}{ }^{B M}=a_{1}{ }^{A M} \\
p \text {-value }\end{array}$ \\
\hline \multicolumn{8}{|c|}{ Panel A: Both demand and supply in (4) } \\
\hline \multirow[t]{2}{*}{ Output gap } & $-0.339^{* * *}$ & $-0.494^{* * *}$ & & & $-0.298^{* * *}$ & $-0.521^{* \star *}$ & \\
\hline & $(0.034)$ & $(0.039)$ & 0.001 & 0.143 & $(0.048)$ & $(0.022)$ & 0.000 \\
\hline \multirow[t]{2}{*}{ Demand } & 0.010 & 0.015 & & & 0.030 & $0.093^{* *}$ & \\
\hline & $(0.017)$ & $(0.020)$ & 0.851 & 0.216 & $(0.020)$ & $(0.038)$ & 0.142 \\
\hline \multirow[t]{2}{*}{ Supply } & -0.101 & $-0.185^{\star *}$ & & & 0.008 & $-0.170^{* *}$ & \\
\hline & $(0.062)$ & $(0.078)$ & 0.008 & 0.216 & $(0.051)$ & $(0.074)$ & 0.049 \\
\hline \multicolumn{8}{|c|}{ Panel B: Either demand or supply in (4) } \\
\hline \multirow[t]{2}{*}{ Demand } & $0.048^{* * *}$ & $0.052^{* * *}$ & & & $0.029^{*}$ & $0.176^{* * *}$ & \\
\hline & $(0.013)$ & $(0.012)$ & 0.763 & 0.000 & $(0.016)$ & $(0.029)$ & 0.000 \\
\hline \multirow[t]{2}{*}{ Supply } & -0.126 & $-0.201^{* *}$ & & & -0.061 & $-0.327^{* * *}$ & \\
\hline & $(0.078)$ & $(0.083)$ & 0.006 & 0.500 & $(0.038)$ & $(0.049)$ & 0.000 \\
\hline \multicolumn{8}{|c|}{ Panel C: Either demand or supply in (4) with a3 $=0$} \\
\hline \multirow[t]{2}{*}{ Output gap } & $-0.341^{* * *}$ & $-0.482^{* * *}$ & & & $-0.297^{* * *}$ & $-0.512^{* \star *}$ & \\
\hline & $(0.031)$ & $(0.036)$ & 0.001 & 0.097 & $(0.043)$ & $(0.020)$ & 0.000 \\
\hline \multirow[t]{2}{*}{ Demand } & $0.044^{* * *}$ & $0.057^{* * *}$ & & & $0.030^{*}$ & $0.195^{\star * *}$ & \\
\hline & $(0.013)$ & $(0.011)$ & 0.002 & 0.000 & $(0.018)$ & $(0.033)$ & 0.000 \\
\hline \multirow[t]{2}{*}{ Supply } & $-0.128^{* *}$ & $-0.204^{* *}$ & & & -0.062 & $-0.370^{* * *}$ & \\
\hline & $(0.061)$ & $(0.082)$ & 0.004 & 0.094 & $(0.044)$ & $(0.056)$ & 0.000 \\
\hline
\end{tabular}

Note: This table refers to the non-discretionary fiscal rule $d_{i, t}-d^{*}{ }_{i, t}=c_{i}^{B M}+c_{i}^{A M}+a_{l}^{B M} \cdot E_{t-l}\left(\right.$ gap $\left.p_{i, t}\right)+$ $a_{1}^{A M} \cdot E_{t-1}\left(\operatorname{gap}_{i, t}\right)+a_{2}^{B M} \cdot\left(d_{i, t}-d^{*}{ }_{i, t}\right)+a_{2}^{A M} \cdot\left(d_{i, t}-d^{*}{ }_{i, t}\right)+a_{3}^{B M} \cdot b_{i, t-1}+a_{3}^{A M} \cdot b_{i, t-1}+u_{i, t}$. Coefficients are reported as well as standard deviation between brackets. *, ** and *** imply significance at the $10 \%, 5 \%$ and $1 \%$ significance level respectively. Equality between $a_{l}^{B M}$ and $a_{l}^{A M}$ is tested by a standard F-test, whose $p$-value is indicated. For the GMM estimator, the instrument space is constituted of the second and third lag of the dependent variable and the one-year lagged US output gap. The adequacy of this instrument space is tested with the Sargan test. The output gap is instrumented in the IV estimator by including the one-year lagged US output gap. 
Table 8: Discretionary fiscal rule, 1985-2004, Demand constraints

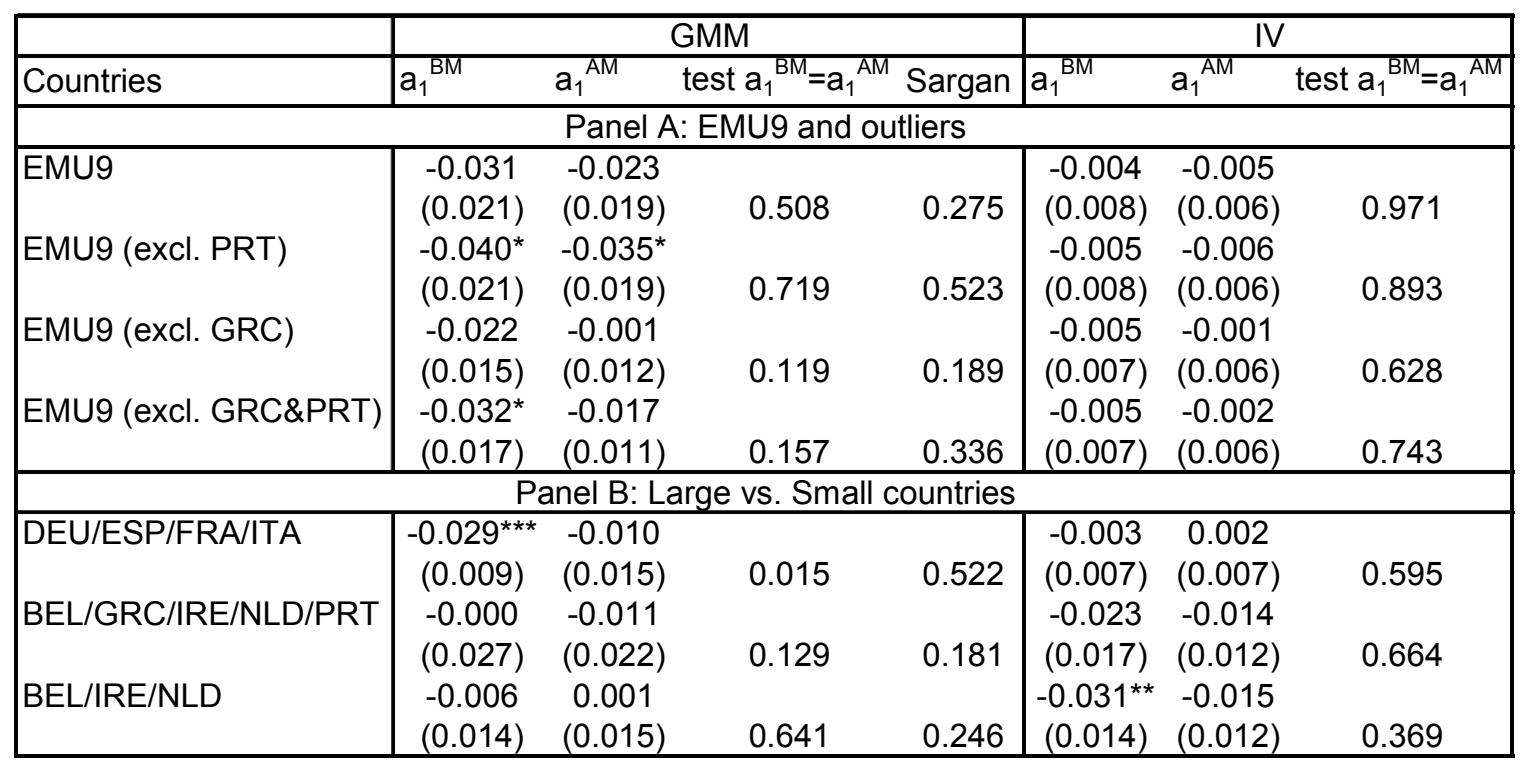

Table 9: Discretionary fiscal rule, 1985-2004, Supply constraints

\begin{tabular}{|c|c|c|c|c|c|c|c|}
\hline & \multicolumn{4}{|c|}{ GMM } & \multicolumn{3}{|c|}{ IV } \\
\hline Countries & $a_{1}{ }^{B M}$ & $a_{1}{ }^{A M}$ & test $a_{1}{ }^{B M}=a_{1}{ }^{A M}$ & Sargan & $a_{1}{ }^{B M}$ & $a_{1}{ }^{A M}$ & test $a_{1}{ }^{B M}=a_{1}{ }^{A M}$ \\
\hline \multicolumn{8}{|c|}{ Panel A: EMU9 and outliers } \\
\hline \multirow[t]{2}{*}{ EMU9 } & 0.052 & $0.092^{*}$ & & & 0,019 & $0.067^{* \star \star}$ & \\
\hline & $(0.040)$ & $(0.048)$ & 0.484 & 0.347 & $(0.015)$ & $(0.023)$ & 0.078 \\
\hline \multirow[t]{2}{*}{ EMU9 (excl. PRT) } & 0.068 & 0.071 & & & 0.020 & $0.072^{\star *}$ & \\
\hline & $(0.049)$ & $(0.057)$ & 0.963 & 0.551 & $(0.016)$ & $(0.028)$ & 0.101 \\
\hline \multirow{2}{*}{ EMU9 (excl. GRC) } & 0.039 & $0.092^{*}$ & & & 0.017 & $0.084^{* \star *}$ & \\
\hline & $(0.029)$ & $(0.054)$ & 0.344 & 0.408 & $(0.013)$ & $(0.021)$ & 0.008 \\
\hline \multirow[t]{2}{*}{ EMU9 (excl. GRC\&PRT) } & 0.048 & 0.069 & & & 0.016 & $0.090^{* * *}$ & \\
\hline & $(0.034)$ & $(0.067)$ & 0.760 & 0.368 & $(0.013)$ & $(0.025)$ & 0.011 \\
\hline \multicolumn{8}{|c|}{ Panel B: Large vs. Small countries } \\
\hline \multirow[t]{2}{*}{ DEU/ES } & 0.013 & 0.074 & & & 0.006 & $0.069^{\star \star *}$ & \\
\hline & $(0.018)$ & $(0.049)$ & 0.070 & 0.313 & $(0.013)$ & $(0.023)$ & 0.021 \\
\hline \multirow[t]{2}{*}{ BEL/GRC/IRE/NLD/PRT } & $-0.111^{*}$ & -0.015 & & & 0.022 & 0.054 & \\
\hline & $(0.059)$ & $(0.068)$ & 0.009 & 0.179 & $(0.041)$ & $(0.038)$ & 0.576 \\
\hline \multirow[t]{2}{*}{ BEL/IRE/NLD } & 0.108 & -0.130 & & & 0.013 & $0.184^{*}$ & \\
\hline & $(0.140)$ & $(0.146)$ & 0.197 & 0.358 & $(0.137)$ & $(0.103)$ & 0.322 \\
\hline
\end{tabular}

Note: Tables 8 and 9 refer to the discretionary fiscal rule $d^{*}{ }_{i, t}=c_{i}^{B M}+c_{i}^{A M}+a_{l}^{B M} \cdot E_{t-l}\left(\operatorname{gap}_{i, t}\right)+$ $a_{1}^{A M} \cdot E_{t-1}\left(\operatorname{gap}_{i, t}\right)+a_{2}^{B M} \cdot d^{*_{i, t-1}}+a_{2}^{A M} \cdot d^{*_{i, t-1}}+a_{3}^{B M} \cdot b_{i, t-1}+a_{3}^{A M} \cdot b_{i, t-1}+u_{i, t}$. Coefficients are reported as well as standard deviation between brackets. ${ }^{*}, * *$ and $* * *$ imply significance at the $10 \%, 5 \%$ and $1 \%$ significance level respectively. Equality between $a_{l}^{B M}$ and $a_{l}^{A M}$ is tested by a standard F-test, whose pvalue is indicated. For the GMM estimator, the instrument space is constituted of the second and third lag of the dependent variable and the one-year lagged US output gap. The adequacy of this instrument space is tested with the Sargan test. The output gap is instrumented in the IV estimator by including the one-year lagged US output gap. For the GMM specification BEL/IRE/NLD the lagged US gap is excluded from the instrument space. The output gap is instrumented in the IV estimator by including the one-year lagged US output gap. 
Figure 1: Supply and Demand Indicators
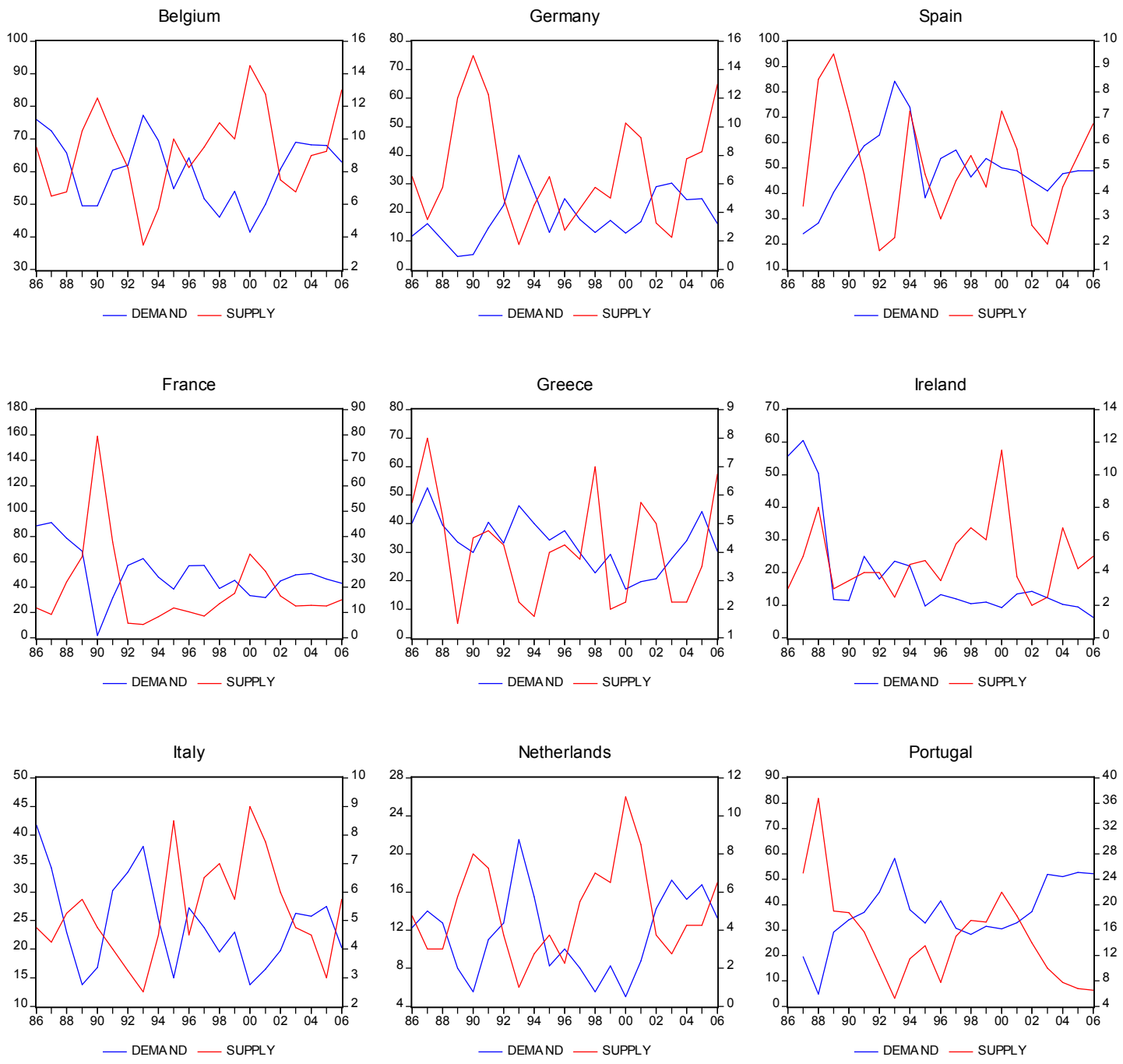

Left and right axis represent the percentage of firms indicating they face demand or supply constraints, respectively. 

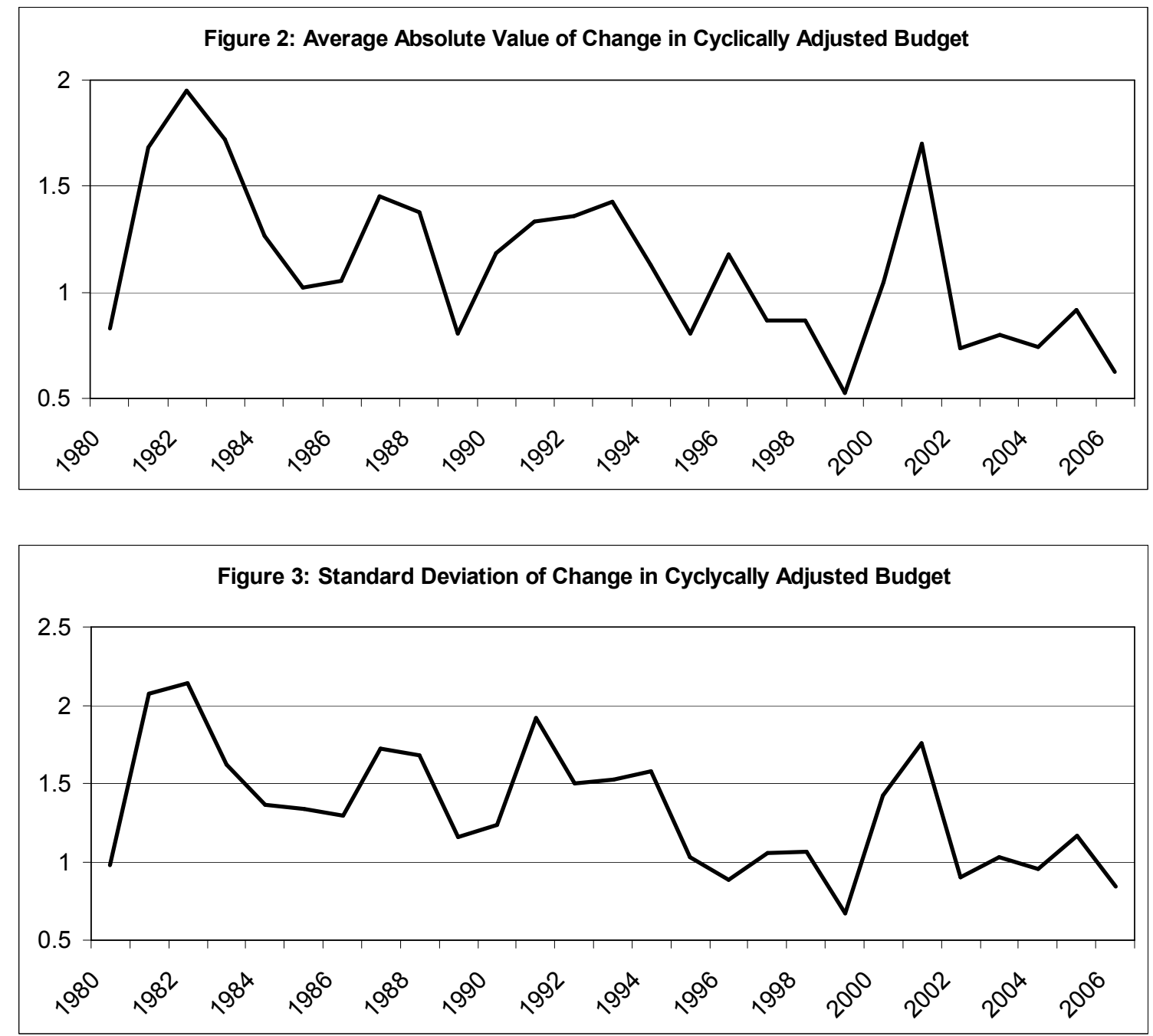